九州大学学術情報リポジトリ

Kyushu University Institutional Repository

\title{
Development of Serum-free Medium for Clonal Growth of Human-human Hybridomas
}

Kuroita, Toshihiro

Graduate School of Genetic Resources Technology, Kyushu University

Shi rahata, Sanetaka

Graduate School of Genetic Resources Technology, Kyushu University

Tachibana, Hi rofumi

Graduate School of Genetic Resources Technology, Kyushu University

Murakami, Hiroki

Graduate School of Genetic Resources Technology, Kyushu University

https://doi.org/10.5109/24108

出版情報：九州大学大学院農学研究院紀要. 40 (1/2)，pp. 223-231，1995-12. Kyushu University バージョン：

権利関係 : 


\title{
Development of Serum-free Medium for Clonal Growth of Human-human Hybridomas
}

\author{
Toshihiro Kuroita*, Sanetaka Shirahata ${ }^{\dagger}$, Hirofumi Tachibana \\ and Hiroki Murakami
}

\author{
Graduate School of Genetic Resources Technology, \\ Kyushu University, Fukuoka 812-81, Japan \\ (Received July 31, 1995)
}

\begin{abstract}
The cloning of human-human hybridomas in serum-free medium may be beneficial to industry and research. Currently, the use of serum is essential when human-human hybridomas are cloned. To develop serum-free medium for cloning human-human hybridomas, we screened a variety of compounds to determine their effects on the clonal grouth of NAT-30 cells, which are derived from the human Burkitt lymphoma Namalwa. These effective compounds were added to ERDF medium supplemented with insulin, transferrin, ethanolamine and sodium selenite (ITES-ERDF). Bovine serum albumin (BSA) and a-tocopherol elevaled clonal coll growth remarkably. Casein significantly stimulated the growth of NAT-SO cells at, relatively lou cell densities. Almost all human-human hybridomas, which were not able to proliferate in ITESERDF medium alone, could grow in ITES-ERDF medium supplemented with BSA, a tocopherol, and casein (ITES-BTC-ERDF medium), Cloning efficiencies of human-human hybridomas cultured in the ITES-BTC-ERDF medium were as high as whencultured in medium supplemented with $15 \%$ fetal calf serum.
\end{abstract}

\section{INTRODUCTION}

Culturing hybridomas in serum-free medium has many advantages (easy purification of monoclonal antibodies (MAbs), low medium cost, medium quality stability, etc.) for the mass-production of MAbs. ERDF medium supplemented with insulin, transferrin, ethanolamine and sodium selenite (ITES-ERDF) has been widely used as a serum-free culture medium for lymphocytes and hybridomas (Murakami et al., 1982; Murakami, 1989). Establishment of human fusion partners such as NAT-30 (Murakami et al., 1985), HO-323 (Ohashi et al., 1986) and A4H12 (Kawahara et al., 1992) make it possible to produce many human-human hybridomas reactive to various human antigens (Hashizume et al., 1987; Shinmoto et al., 1988; Aihara et al., 1988). However, ITES-ERDF medium not only does not support the growth of some hybridomas, but the cloning of lymphoid cells and hybridomas in this serum-free medium is impossible because of poor cell growth at low cell densities. Even hybridomas which can grow in ITES-ERDF medium must use serum-supplemented medium for cloning, which may result in an unfavorable selection of cells. Serum is also expensive and cloning efficiencies vary from serum lot to lot.

This background prompted us to develop a new serum-free medium that will allow for the cloning of human-human hybridomas. There are several factors which affect cloning efficiencies: (1) damage by oxygen radicals, (2) deficiencies of various autocrine growth factors, and (3) physical cell damages. Among these factors, the most important factor

"Present address: Toyobo Co. Itd. 2-8 Dojima Hama 2-chome Kita-kiu, Osaka 5:31, Japan

To whom correspondence should be addressed. 
negatively influencing clonal growth seems to be the damage caused by oxygen radicals (Darfler \& Insel, 1983), particularly in serum-free medium which lacks free radical capturing potency (Mulholland \& Strain, 1991). Clonal growth of lymphoid cells is known to be inhibited by $\mathrm{H}_{3} \mathrm{O}_{2}$ in serum-free medium which produces hydroxyl radical (Darfler \& Insel, 1983). It has been reported that reducing agents such as mercaptoethanol (Kan \& Yamane, 1982) and anti-oxidant reagents such as a-tocopherol (Gavino et al., 1981) are able to elevate the cloning efficiency. Human hybridomas are generally more susceptible to chemical and physical damage than murine hybridomas. In fact, as far as we know, there has been only one report which briefly describes the development of a serum-free medium in which the cloning of a human hybridoma cell line is possible.

This paper reports that ITES-ERDF medium supplemented with BSA, a-tocopherol, and casein can clone human-human hybridomas as efficiently as serum-supplemented medium, and is able to support serial passages of human-human hybridomas which are not able to proliferate in ITES-ERDF medium alone.

\section{MATERIALS AND METHODS}

\section{Reagents}

BSA (fraction V, Sigma, U.S.A.) and casein (Wako Pure Chemicals, Japan) were dissolved in phosphate-buffered saline (PBS). Egg yolk lipoprotein (YLP) was prepared by the method described previously (Murakami et al., 1988). a-Tocopherol, ascorbic acid, dithiothreitol and 2-mercaptoethanol were purchased from Wako Pure Chemicals and dissolved in ethanol. MTT reagent was obtained from Dojin Chemicals (Japan).

\section{Cells and cell culture}

NAT-30 cells are a 6-thioguanin-resistant clone derived from human Burkitt lymphoma Namalwa cells (Murakami et al., 1985). HB4C5 and HF10B4 cells are humanhuman hybridomas obtained by the fusion of NAT-30 cells with human lymph node lymphocytes. HO-323 cells were established as a parent cell line from the human lymphoblast WIL2-NS (Ohashi et al., 1986). EMK-F7 cells are hybridomas produced by the fusion of HO-323 cells with human lymph node lymphocytes (Koyama et al., 1990). BD9-D12 cells are hybridomas produced by the fusion of A4H12 cells, a human parent cell line with human lymph node lymphocytes (Kawahara et al., 1992).

NAT-30 cells and hybridomas derived from NAT-30 cells were cultured in ERDF medium supplemented with ITES (insulin, $5 \mu \mathrm{g} / \mathrm{ml}$; transferrin, $10 \mu \mathrm{g} / \mathrm{ml}$; ethanolamine, $25 \mu \mathrm{M}$; and sodium selenite, $2 \mathrm{nM}$ ) at $37^{\circ} \mathrm{C}$ in a humidified atmosphere of $95 \%$ air $/ 5 \% \mathrm{CO}$, Other cells were cultured in ITES-ERDF medium supplemented with $50 \mu \mathrm{g} / \mathrm{ml}$ of BSA, 1 $\mu \mathrm{M}$ of a-tocopherol and $50 \mu \mathrm{g} / \mathrm{ml}$ of casein.

\section{Measurement of cell growth}

MTT assay was used to measure the growth stimulating effect of various compounds on cultured cells (Mosmann, 1983). 
Screening of compounds promoting clonal cell growth in serum-free medium

Compounds which promote cloning efficiencies were screened using two method; limiting dilution method and colony formation assay. In the limiting dilution method, cells were plated at 1 cell/well in a 96 -well microplate in serum-free medium containing the compounds to be examined. After incubating for 7 days, the number of wells containing growing cells were counted. Simultaneously, a more convenient assay method for detecting colony formation was also developed. Cells were plated at 10 cells/well in a $96-$ well microplate in serum-free medium containing the compounds to be examined. After statically incubating the plate for 7 days, the number of colonies formed was counted using a microscope and the colony formation ratio (\%) was calculated.

\section{RESULTS}

Screening of compounds which are able to promote the growth of NAT-30 cells in serum-free medium

Effects of various compounds on the growth of NAT-30 cells at a low cell density were examined in ITES-ERDF medium. As shown in Fig. 1, casein remarkably stimulated the growth of NAT-30 cells at a low cell density ( 3 X 10' cells $/ \mathrm{ml})$ when applied in a wide range of concentrations $(1-100 \mu \mathrm{M})$. YLP showed a maximum stimulating effect at 10 $\mu \mathrm{g} / \mathrm{ml}$, but caused a severe cell damage at concentrations higher than $20 \mu \mathrm{g} / \mathrm{ml}$. BSA exhibited a weak growth stimulating effect. Antioxidants such as a-tocopherol and

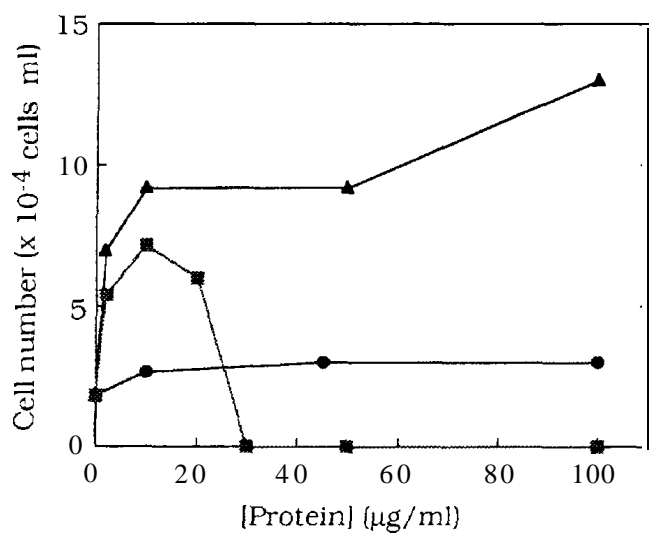

Fig. 1. Effects of BSA, casein and YLP on the growth of NAT-30 cells. NAT-30 cells were seeded in a 96-well microplate at a concentration of $3 \times 10^{4}$ cells/well in $0.1 \mathrm{ml}$ of ITES-ERDF medium containing various concentrations of BSA, casein and YLP. After incubation for 4 days, the relative cell numbers were measured using the MTT method. Average value in triplicate is shown in the figure. Standard deviation (S.D.) is within $10 \%$. BSA ; $\mathbf{\Delta}$, casein ; $\mathbf{D}$, YLP 
ascorbic acid and reducing agents such as 2-mercaptoethanol and dithiothreitol also showed weak growth stimulating effects (data not shown).

Screening of compounds which are able to promote the clonal growth of NAT-30 cells in serum-free medium

Next, effects of various compounds on the clonal growth of NAT-30 cells were examined using the colony formation assay. As shown in Fig. 2A, BSA stimulated the
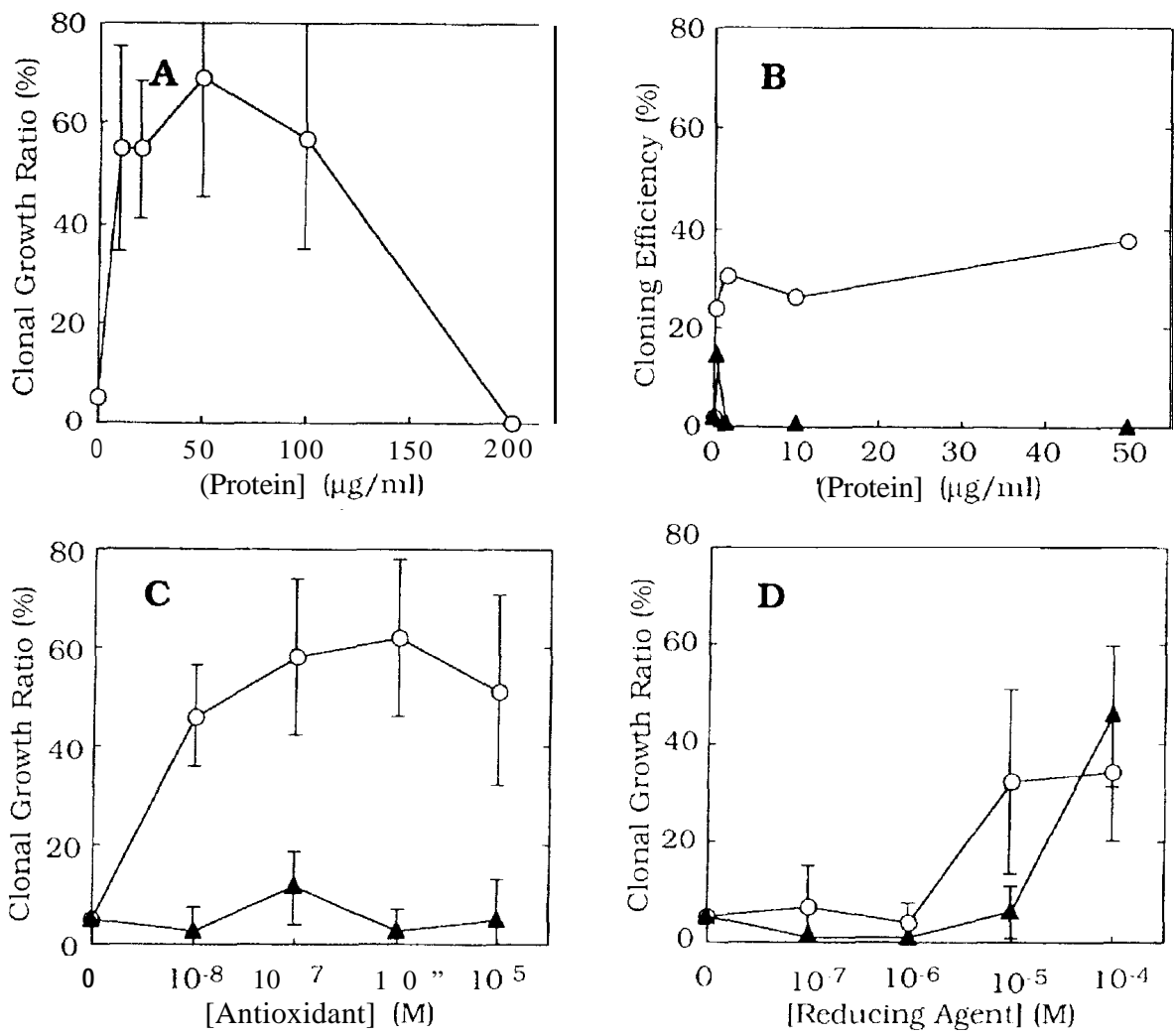

Fig. 2. Effects of BSA, casein, YLP, $\alpha$-tocopherol, ascorbic acid, dithiothreitol and 2Inercaptoethanol on the clonal growth of NAT-30 cells. (A) NAT-30 cells were plated in a 96-well microplate at. a concontration of 10 cells/well in ITES-ERDF medium containing various concentrations of BSA. After 7 day, the colonies formed werecounted. Clonal growth ratio $(\%)$ was calculated by dividing the number of colonies by 10 . Vertical bar represents S.D. $(\mathrm{N}=6)$ ). (B) Cells were plated in a 96-well microplate at a density of 1 cell/well in ITES-ERDF medium containing various concentrations of casein or YLP. After 7 days., the percentage of wells containing growing cells n-w-r determined Average value in triplicate is shown in the figure. S.D. is within $10 \%$. $\bigcirc$, casem, A, YLP. (C) Effects of a-tocopherol and ascorbic acid on the clonal growth of NAT-30 rells n-err examined under the same conditions $3 \mathrm{~s}$ in $(\mathrm{A}) \mathrm{O}$, a -tocopherol; $\Delta$, ascorbic acid Vertical bar represents S.D. $(\mathrm{N}=6)$. (D) Effects of reducing agents, dithothreitoland2mercaptoethanolwere examined under thesame conditions as in (A). Z, dithothreitol; A. 2-moraptoethanol. Vertical bar represents S.D. $(\mathrm{N}=6)$. 
clonal growth of NAT-30 cells noticeably. The maximum colony formation ratio $(60 \%)$ was obtained at a BSA concentration of $50 \mu \mathrm{g} / \mathrm{ml}$ and cell damage was observed at concentrations over $200 \mathrm{\mu g} / \mathrm{ml}$. Since casein caused a tendency for cell to move to the edge of the well at concentrations higher than $50 \mu \mathrm{g} / \mathrm{ml}$, cloning efficiencies were examined using the limiting dilution method, instead of the colony formation assay. Casein was shown to elevate the cloning efficiency at concentrations higher than $1 \mu \mathrm{g} / \mathrm{ml}$ (Fig. 2B). However, YLP, which strongly stimulates cell growth, inhibited clonal growth completely at concentrations higher than $1 \mathrm{\mu g} / \mathrm{ml}$. As shown in Fig. 2c, a-tocopherol, an antioxidant, exceptionally elevated the colony formation ratio to $60 \%$ at $1 \mu \mathrm{M}$. Whereas, ascorbic acid, an another antioxidant, showed no stimulating activity. Reducing agents such as 2-mercaptoethanol and dithiothreitol elevated the colony formation ratio to $40 \%$ at a relatively high concentration of $100 \mu \mathrm{M}$ (Fig. 2D).

Next, the combined effects of BSA and a-tocopherol were examined. As shown in Fig. 3, supplementation of both BSA and a-tocopherol to the ITES-ERDF medium resulted in a high colony formation ratio of about $80 \%$. Further addition of casein to the ITES-ERDF medium supplemented with BSA and a-tocopherol did not lowered the cloning efficiency, but addition of YLP inhibited the clonal growth completely at concentrations higher than $10 \mu \mathrm{g} / \mathrm{ml}$ (data not shown).

From the results obtained, the supplementation of BSA $(50 \mu \mathrm{g} / \mathrm{ml})$, a-tocopherol ( 1 $\mu \mathrm{M})$ and casein $(50 \mu \mathrm{g} / \mathrm{ml})$ to ITES-ERDF medium was very effective for elevating both the cloning efficiency and growth rate.

Growth and cloning efficiencies of various kinds of cell lines in ITES-ERDF medium supplemented with BSA, a-tocopherol and casein

The growth rate of various cell lines were examined in ITES-ERDF medium

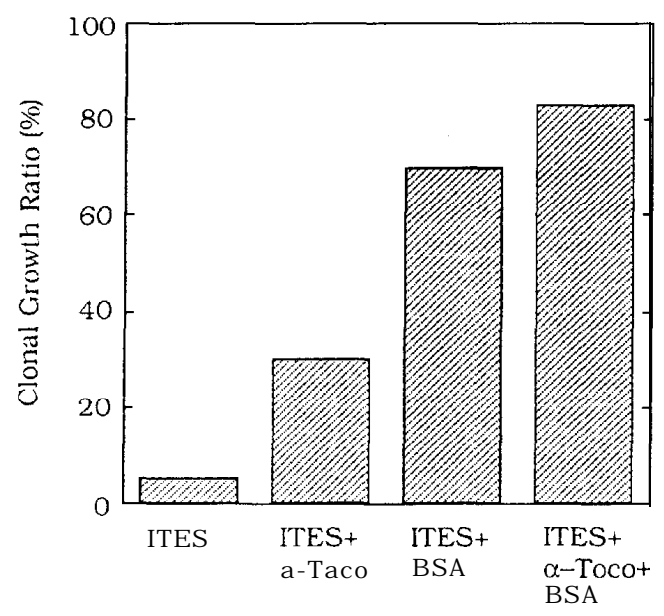

Fig. 3. Clonal growth ratio of NAT-30 cells in ITESERDF medium supplemented with $\alpha$ tocopherol and BSA. The experimental conditions are the same as in Fig. 2 (A). $\alpha$ Tocopherol, $1 \mu \mathrm{M}$; BSA, $50 \mu \mathrm{g} / \mathrm{ml}$. 
supplemented with BSA $(50 \mu \mathrm{g} / \mathrm{ml})$, a-tocopherol $(1 \mu \mathrm{M})$ and casein $(50 \mu \mathrm{g} / \mathrm{ml})$ (ITESBTC-ERDF medium). NAT-30 cells and the two hybridomas derived from these cells, all of which were able to grow in ITES-ERDF medium, could also actively proliferate in ITESBTC-ERDF medium. When plated at a density of $1 \times 10^{4} \mathrm{cells} / \mathrm{ml}$, the growth rates of cells grown in ITES-BTC-ERDF medium were lower than cells grown in ERDF medium supplemented with $15 \%$ fetal bovine serum (FCS) (Fig. 4A). HO-323 cells and their hybridoma EMK-F7, and A4H12 cell and their hybridoma BD9D-12, could also grow well in ITES-BTC-ERDF medium, but grew poorly in ITES-ERDF medium (Fig. 4B and 4C). Serial passages of all cells mentioned above were possible for a long period of time, although the doubling time in ITES-BTC-ERDF medium was longer than that in serumcontaining medium.

Next, the cloning efficiencies of these cells cultured in ITES-BTC-ERDF medium or 15\% FCS-ERDF medium were examined. The results are shown in Table I. Hybridomas derived from NAT-30 and HO-323 cell lines in ITES-BTC-ERDF medium showed a similar cloning efficiency as in serum-containing medium. HF10B4 cells showed a 1 .\&fold higher efficiency rate in ITES-BTC-ERDF medium than in serum-containing medium. A4H12 cells and their hybridomas derived from these cells showed lower cloning efficiencies in ITES-BTC-ERDF medium than in serum-containing medium. When $\mathrm{O}_{2}$ concentration was lowered to $5 \%$, the cloning efficiency of NAT-30 cells in ITES-BTC-ERDF medium elevated 1.6-fold, as compared to cells cultured in an atmosphere of $5 \% \mathrm{CO}_{2} / 95 \%$ air.

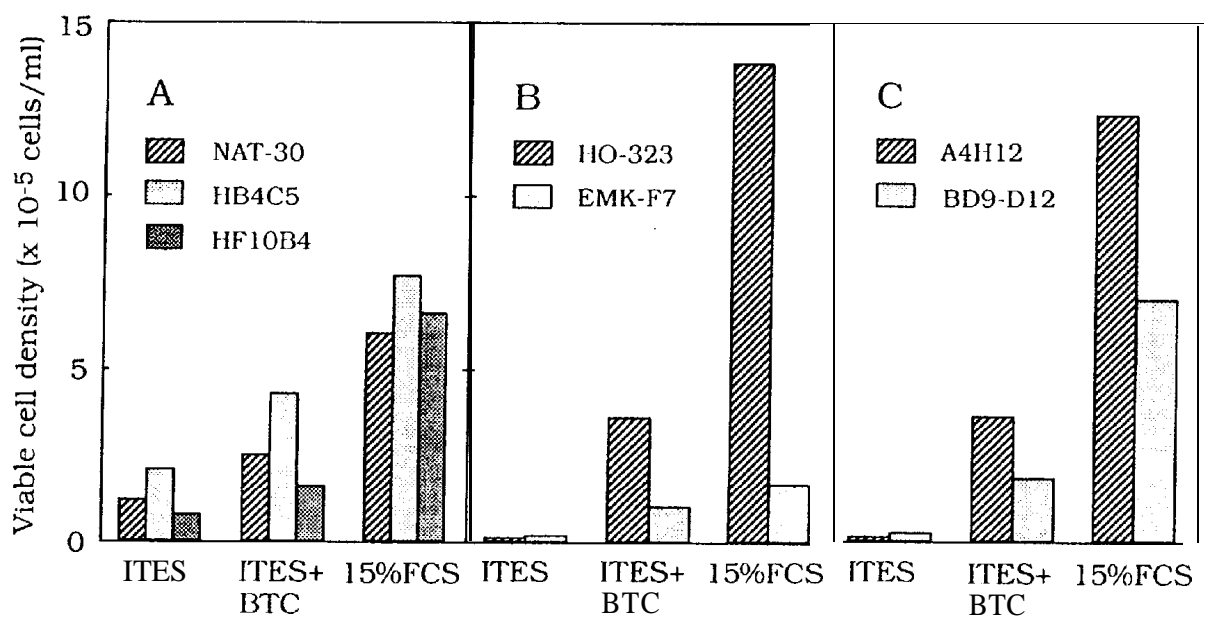

Fig. 4. Comparison of growth of lymphoid cells and their hybridomas in ITES-ERDF, ITES-BTCERDF, and $15 \%$ FCS-ERDF medium. Cells were plated in a 96-well microplate at a concentration of 1 X 10' cells/ml per well. After 4 days, the cell number was counted with a cell counter. Viability was measured using the trypan blue exclusion method. (A) Growth of NAT-30 cell line and its hybridomas, HB4C5 and HF10B4. (B) Growth of HO323 cell line and its hybridoma EMK-F7. (C) Growth of A4H12 cell line and its hybridoma BD9-D12. 
Table 1. Comparison of the cloning efficiencies of various lymphoid cells and hybridomas grown in ITES-BTCERDF medium and $15 \%$ FCS-ERDF medium.

\begin{tabular}{lccc}
\hline & \multicolumn{2}{c}{ Cloning efficiencies $(\%){ }^{*}$} & ITES-BTC/15\% FCS \\
\cline { 2 - 3 } & ITES-BTC” & 15\% FCS & \\
\hline Namalwa & 88 & 31 & 2.80 \\
NAT-30 & 40 & 40 & 1.00 \\
NAT-30 & 63 & 58 & 1.07 \\
HB4C5 & 67 & 50 & 0.94 \\
HF1OB4 & 48 & 29 & 1.64 \\
HO-323 & 54 & 54 & 1.08 \\
EMK-F7 & 46 & 44 & 1.05 \\
A4H12 & 58 & 67 & 0.88 \\
BD9-D12 & 25 & 50 & 0.50 \\
\hline
\end{tabular}

' Cells subcultured in ITES-BTC-ERDF medium were plated on a 96-well microplate at a density of 1 cell/well in ITES-BTCERDF medium or in $15 \%$ FCS-ERDF medium under an atmosphere of $5 \% \quad \mathrm{CO} / 95 \%$ air. After 7 days, the percentage of wells containing growing cells were determined.

n ITES-BSA $(50 \mu \mathrm{g} / \mathrm{ml})+\alpha$-tocopherol $(1 \mu \mathrm{M})+$ casein $(50$ $\mu \mathrm{g} / \mathrm{ml}$ )

' $\mathrm{O}_{2}$ concentration decreased to $5 \%$.

\section{DISCUSSION}

ITES-ERDF medium supports the cell growth of human lymphoid cells and humanhuman hybridomas at high cell densities (e. g. $1 \times 10$ " cells $/ \mathrm{ml}$ ), however these same cells grow poorly at lower cell densities (e. g. $1 \times 10^{4}$ cells $/ \mathrm{ml}$ ). This stimulating effect of serum on cell growth when plated at a low cell density is not dependent upon differing serum lots. However cloning efficiencies of hybridomas in serum-supplemented medium varies dependent upon serum lot to lot. These facts suggest serum contains components which support both the cell growth at low cell densities and clonal cell growth. For example, human plasma and the conditioned medium of human-human hybridoma cells contain lymphocytic clonal growth factors (Miyata et al., 1988a; Miyata et al., 1988b).

For the development of a new serum-free medium which supports the cloning of human lymphoid cells and human-human hybridomas, we used three kinds of human fusion partners and their hybridomas. NAT-30 cells and hybridomas derived from this cell line can grow well in ITES-ERDF medium as well as in serum-supplemented medium. HO-323 cells can grow in ITES-ERDF medium, but hybridomas derived from this cell line need further supplementation, in particular YLP, to grow in the serum-free medium. A4H12 cells and hybridomas derived from these cells can not grow in serum-free medium. Among these cells, NAT-30 cells were used to screen for effective compounds that, when added to serum-free medium, may support the cloning of lymphoid cells and humanhuman hybridomas. 
As a result of screening, casein and YLP were found to be effective to stimulate the cell growth of NAT-30 cells grown at a density of $3 \times 10^{4}$ cells $/ \mathrm{ml}$. Also, the clonal growth of NAT-30 cells was accelerated by BSA and a-tocopherol. Since YLP strongly inhibited the clonal growth of NAT-30 cells, casein, along with BSA and $\alpha$-tocopherol, was chosen as supplements for our serum-free medium.

ITES-BTC-ERDF medium supported the cloning of almost all lymphoid cell lines and hybridomas. Although cell growth was slower than in 15\% FCS-supplemented medium, all colonies grew actively. In addition, all lymphoid cell lines and hybridomas tested could also grow in ITES-BTC-ERDF medium. When cells were plated at density of 1 X 10, cells/ml, cell growth was slower in ITES-BTC-ERDF medium than in $15 \%$ FCSsupplemented medium. However, for cells plated at a density of $1 \times 10^{5}$ cells $/ \mathrm{ml}$ in ITESBTC-ERDF medium, the growth rate was comparable to cells growing in serumcontaining medium. The fact that cloning cells under a $5 \% \quad \mathrm{O}_{2}$ atmosphere resulted in an elevation of the cloning efficiency suggests that clonal growth is inhibited by oxygen radicals.

YLP stimulates the cell growth of lymphoid cells via the supply of fatty acids (Murakami et al., 1988). However, the oxidation of fatty acids in medium will produce lipid peroxides, which generate oxygen radicals, in particular hydroxyl radicals, resulting in cell damage (Spieker-Polet \& Polet, 1981; Wang et al., 1991). High concentrations of YLP was toxic to NAT-30 cells, perhaps due to lipid peroxides. a-Tocopherol, an antioxidant, traps radicals in medium (Dean et al., 1991). Ascorbic acid, another antioxidant, did not stimulate the clonal growth of NAT-30 cells. The instability of ascorbic acid may be related to its ineffectiveness (Border et $a l ., 1983$ ).

Although trace amounts of fatty acids are indispensable for normal cell growth, the prevention of fatty acids oxidation plus the detoxification of oxygen radicals formed by fatty acids oxidation are important considerations to take into account when developing serum-free medium for cloning (Darfler, 1990). Darfler and Insel (1983) developed a serum-free medium supplemented with catalase, testosterone, and dilinoleoyl phosphatidylcholine to clone a human hybridoma cell line. However, catalase, testosterone and dilinoleoyl phosphatidylcholine are expensive making it inappropriate for use in industry.

Since the serum-free medium developed here supports both the cloning and the cell growth of almost all human-human hybridomas at low cell densities, analysis of MAbs will become easier. The supply of stable and inexpensive serum-free medium will contribute to experimental reproducibility and facilitate mass and high density culture of humanhuman hybridomas, which before could not be cultured in serum-free medium.

\section{REFERENCES}

Aihara, K., K. Yamada, H. Murakami , Y. Nomura and H. Omura. 1988 Production of human-human hybridomas secreting monoclonal antibodies reactive to breast cancer cell lines. InVitro Cell. Develop. Biol., 24: 959-962

Boder, G. B., W. J. Kleinschmidt,, R. J. Harley and D. C. Williams. 1983 Eur.J.Cell Biol., 31: 132-136

Darfler, F. J 1990 Preparation and use of lipid microemulsions as nutritional supplements for culturing mammalian cells. InVitro Cell.Dev.Biol., 26: 779-783

Dean, R. T., J. V. Hunt, A. J. Grant, Y. Yamamoto and E. Niki. 1991 Free radical damage to proteins: the 
influence of the relative localization of radical generation antioxidant and target proteins. Free radical Biol. Med. 11: 161-168

Darfler, F. J. and P. A. Insel. 1983 Clonal growth of lymphoid cells in serum-free media requires elimination of $\mathrm{H}_{2} \mathrm{O}$. toxicity. J.Cell. Physiol., 115: 31-36

Gavino, V. C., J. S. Miller, S. 0. Ikharebha, G. E. Milo and D. G. Cornwell. 1981 Effect. of polyunsaturated fatty acids and antioxidants on lipid peroxidation in tissue cultures. J. Lipid Res., 22: 763-769

Hashizume, S., H. Murakami, M. Kamei,S. Hirose, T. Shirai, K. Yamada and H. Omura. 1987 Specificity of anti-polynucleotide monoclonal antibodies from human-human hybridomas. InVitro Cell.Biol, 23: 53-56

Kan, M. and I. Yamane. 1982 Effects of sulfhydryl groups and oxygen tension on the cell proliferating activity of bovine serum albumin in culture. Cell Struct Funct., 7: 135-144

Kawahara, H., S. Shirahata, H. Tachibana and H. Murakami. 1992 In vitro immunization of human lymphocytes with human lung cancer cell line A549. Hum. Antibod. Hybridomas, 3: 8-13

Koyama, K., K. Akiynma, H. Kawahara, A. Egashira and H. Murakami. 1990 Alloimmunization with cultured hurnan stomach cancer cell lines and the establishment of human-human hybridomas producing monoclonal antibodies. Jpn.J.Cancer Res., 81: 967-970

Ohashi, H., S. Hashizume, H. Murakami, K. Aihara, K. Shinohara and Il. Omura. 1986 HO-323, a human B lymphoblastoid cell line useful for making human-human hybridomas. Cell Biol. Inll. Rep., 10: 77-83

Miyata, M., S. Hashizume, H. Murakami, K. Yamada and H. Omura. 1988 Characterization and application of lymphocytic clonal growth factor in human plasma. Cytotechnology, 1: 233-24 1

Miyata, M., H. Murakami, S. Hashizume, K. Yamada and H. Omura. 1988b Purification and characterization of lymphocytic clonal growth factor (LCGF) derived from human-human hybridoma XI-76 cells. Cytotechnology, 1: 347-353

Mosmann, T. 1983 Rapid colorimetric assay for cellular growth and survival: Application to proliferation and cytotoxicity assays. J.Immunol. Methods, 65: 55-63

Mulholl, C.W. and J. J. Strain. 1991 Serum total free radical trapping ability in acute myocardial infraction. Clin. Biochem., 24: 437-442

Murakami, H. 1989 Serum-free media used for cultivation of hybridomas $I n$ : "Advances in Biotechnological Press", Vol. 11, Alan R. Liss Inc., pp.107-141

Murakami, H., S. Hashizume and H. Ohashi. 1985 Human-human hybridomas secreting antibodies specific to human lung carcinoma. In Vitro Cell Develop. Biol. 21: 593-596

Murakami, H., H. Masui, G. H. Sato, N. Sueoka, T. P. Chow and T. Kano- Sueoka. 1982 Growth of hybridoma cell in serum-free medium: ethanolamine is an essential component. Proc. Natl.Acad Sci. USA 79: 1158-1162

Murakami, II., Y. Okazaki, K. Yamada and H. Omura. 1988 Egg yolk lipoprotein. a new supplement for the growth of mammalian cells in serum-free medium. Cytotechnology 1: 159-169

Ohashi, H., S. Hashizume, H. Murakami, K. Aihara, K. Shinohara and H. Omura. 1986 HO-323, a human Blymphoblastoid cell line useful for making human-human hybridomas. Cell Biol.Intem. Reports 10: $77-83$

Shinmoto, H., H. Murakami, S. Dosako, K. Yamada and H. Omura. 1988 Human hybrid immunoglobulin M containing immunoglobulin A. In VitroCell.Devel.Biol. 24: 505-510

Spieker-Polrt, H and H. Polet. 1981 Requirement, of a combination of a saturated and an unsaturated free fatty acid and a fatty acid carrier protein for invitro growth of lymphocytes. J.Immumol. 126: 949954

Wang, J., E. Zhen, Z. Guo and Y. Lu. 1991 Effect of hyperlipidemic serum on lipid peroxidation synthesis of prostacyclin and thromboxane by cultured endothelian cells: protective effect of antioxidants. Free Radical Biol. Med. 7: 243-250 